\author{
Kamil Wasilkiewicz
}

https://orcid.org/0000-0002-4435-9766

(Gniezno)

\title{
ZARYS DZIEJÓW BALIWATU BRANDENBURSKIEGO JOANNITÓW DO KOŃCA XVI W. WPEYW REFORMACJI NA JEGO FUNKCJONOWANIE
}

\footnotetext{
Abstract

The article discusses selected fragments of history of the Bailiwick of Brandenburg, a jurisdiction of the Knights Hospitaller until the end of the 16th century, showing structural transformations it underwent over the centuries. Having outlined the social and political foundation of its functioning, the author presents the influence that the Reformation had on the bailiwick.
}

\section{Key words}

Bailiwick of Brandenburg, Knights Hospitaller, Reformation, military orders 


\section{POWSTANIE BALIWATU}

Baliwat brandenburski był jednostką administracyjną w zakonie joannitów, która w XIV w. powstała w wielkim przeoracie Niemiec ${ }^{1}$. Na jego czele stał mistrz tytułowany $\mathrm{w}$ średniowieczu preceptorem (najczęściej preceptorem generalnym) albo baliwem, a od czasów reformacji - herrenmeistrem ${ }^{2}$.

Struktury baliwatu kształtowały się od XII w. Najstarsza komturia, która później znalazła się w jego granicach, została ufundowana w 1160 r. w Werben (Saksonia-Anhalt, powiat Stendal) przez margrabiego brandenburskiego Albrechta Niedźwiedzia (1157-1170) ${ }^{3}$. W XIII w. na obszarze Meklemburgii powstała grupa powiązanych z nią domów zakonnych: w Groß Eichsen (Meklemburgia-Pomorze Przednie, powiat Nordwestmecklenburg; pomiędzy 1200 i 1217 r.) $)^{4}$, Sülstorfie (Meklemburgia-Pomorze Przednie, powiat Ludwigslust-Parchim; w 1217 r.; pomiędzy 1292 i 1323 r. konwent przeniesiono do Kraak) ${ }^{5}$, Mirow (Meklemburgia-Pomorze Przednie, powiat Mecklenburgische Seenplatte; w 1226/1227) ${ }^{6}$, Gardow (Meklemburgia-Pomorze Przednie, powiat Mecklenburgische Seenplatte; komturia wyodrębniła się z Mirow pomiędzy 1286 i 1298 r.) ${ }^{7}$ i Nemerow (Meklemburgia-Pomorze Przednie, powiat Mecklenburgische Seenplatte; ok. 1300 r. $)^{8}$.

Komturzy z Werben posiadali wysoką pozycję w lokalnych strukturach zakonnych, co przejawiało się mianowaniem niektórych $\mathrm{z}$ nich na ponadregionalne urzędy, które można łączyć z późniejszym urzędem preceptora (generalnego) baliwatu. Do tego grona należałoby zaliczyć mistrza Henryka, który według ustaleń Marka Smolińskiego już w 1217 r. przewodził joannitom z Brandenburgii, Meklemburgii i Szwerynu'. Warto także wspomnieć o Ulryku von Vellebergu, w 1271 r. komturze w Werben oraz wicepreceptorze na Saksonię i Słowiańszczyznę, którego Christian Gahlbeck wskazał jako pierwszą osobę powiązaną z baliwatem brandenburskim, czy też, jak to określił, protobaliwatem ${ }^{10}$.

${ }^{1}$ Zob. Rödel 1972; Borchardt 2014, s. 63-76.

${ }^{2}$ Sarnowsky 2001, s. 175.

${ }^{3}$ Zob. Partenheimer i Knüvener 2007, s. 1289-1304; Partenheimer 2014, s. 173-203.

${ }^{4}$ Zob. Joost i in. 2016, s. 281-299.

${ }^{5}$ Zob. Joost, Neustadt i Amelung 2016a, s. 403-418; Joost, Neustadt i Amelung 2016b, s. 1093-1105 .

${ }^{6}$ Zob. Gahlbeck, Holst i Szczesiak 2014, s. 481-541; Szczesiak i Gahlbeck 2014, s. 207-223.

${ }^{7}$ Zob. Szczesiak i Gahlbeck 2014, s. 223-227; Huschner, Gahlbeck i Szczesiak 2016, s. 317-328.

${ }^{8}$ Zob. Szczesiak i Gahlbeck 2014, s. 227-236; Huschner, Szczesiak i Gahlbeck 2016, s. 544-578.

${ }^{9}$ Smoliński 2008, s. 152.

${ }^{10}$ Gahlbeck 2016, s. 104. 
Kluczowym momentem $\mathrm{w}$ procesie tworzenia się baliwatu była likwidacja zakonu templariuszy (bulla „Vox in excelso” z dn. 3 kwietnia 1312 r.) ${ }^{11}$ i papieski nakaz przekazania ich posiadłości joannitom (bulla „Ad providam” z dn. 2 maja 1312 r. $)^{12}$. W ten sposób w rękach szpitalników znalazły się liczne komturie położone w Brandenburgii, Dolnej Saksonii i na Pomorzu Zachodnim - w Chwarszczanach (niem. Quartschen, woj. zachodniopomorskie, powiat myśliborski) ${ }^{13}$, Czaplinku (niem. Tempelburg, woj. zachodniopomorskie, powiat drawski) ${ }^{14}$, Leśnicy (niem. Lietzen, Brandenburgia, powiat Märkisch-Oderland) ${ }^{15}$, Sulęcinie (niem. Zielenzig, woj. lubuskie, powiat sulęciński) ${ }^{16}$, Tempelhofie (obecnie $\mathrm{w}$ granicach administracyjnych Berlina) ${ }^{17}$, Wielkiej Wsi (niem. Großendorf, woj. lubuskie, powiat sulęciński) ${ }^{18}$, Rurce (niem. Rörchen, woj. zachodniopomorskie, powiat gryfiński) ${ }^{19}$, Brunszwiku (niem. Braunschweig, Dolna Saksonia, miasto na prawach powiatu) ${ }^{20}$, Süpplingenburgu (Dolna Saksonia, powiat Helmstedt) ${ }^{21}$, Quanthofie (obecnie część Benstorf, Dolna Saksonia, powiat Hameln-Pyrmont) ${ }^{22}$ i być może w Emmerstedt (obecnie część Helmstedt, Dolna Saksonia, powiat Helmstedt) ${ }^{23}$.

Proces przejmowania oraz integracji strukturalnej wymienionych domów zakonnych był długotrwały i pełen komplikacji (np. w posiadaniu Sulęcina joannici znaleźli się dopiero w lutym $1351 \mathrm{r}$. $)^{24}$. Początkowo za realizację tego zadania odpowiadał Paweł z Modeny, który od ok. 1316 r. był przedstawicielem wielkiego mistrza Fulka de Villareta (1305-1319) w prowincji Alemania ${ }^{25}$.

${ }^{11}$ Baron i Pietras 2003, s. 465-482.

12 Tamże, s. 483-494.

${ }^{13}$ Zob. Rymar 2002, s. 11-47; Gahlbeck i Schumann 2007, s. 991-115; Burzyński 2010, s. 60-93; Schumann 2014, s. 425-433; Wasilkiewicz 2016a, s. 93-108, 169-185.

${ }^{14}$ Zob. Hoogeweg 1925, s. 895-897; Lüpke 1933, s. 43-97; Burzyński 2010, s. 131-134; Wybranowski 2016, s. 356.

${ }^{15}$ Zob. Hope 1994-1995, s. 11-18; Wigger i Schumann 2007, s. 805-815; Burzyński 2010, s. 45-60; Schumann 2014, s. 413-424; Wasilkiewicz 2016a, s. 108-115, 186-194.

${ }^{16}$ Zob. Gahlbeck 2007d, s. 1338-1344; Burzyński 2010, s. 93-102; Wasilkiewicz 2016a, s. 115-121.

${ }^{17}$ Zob. Stróżyk 1992, s. 5-22; de Nève, Cante i Wittkopp 2007, s. 1275-1288; Knüvener 2014, s. $394-411$.

${ }^{18}$ Zob. Hope 1993, s. 29-32; Gahlbeck 2007a, s. 543-550; Burzyński 2010, s. 121-127.

${ }^{19}$ Zob. Hoogeweg 1925, s. 857-867, 897-904; Breitsprecher 1940; Kołosowski i Siemińska 2014, s. 442-451; Wybranowski 2016, s. 358-365.

${ }^{20}$ Zob. Rödel 1972, s. 424-425; Steinführer 2012a, s. 142-143.

${ }^{21}$ Zob. von Winterfeld 1859, s. 781-782; Rödel 1972, s. 437-438; Weber 2002, s. 44-66; Berwinkel 2012b, s. 1403-1408.

${ }^{22}$ Zob. Heutger 2007, s. 74; Gahlbeck 2014, s. 305, 307.

${ }^{23}$ Zob. Berwinkel 2012a, s. 391-392.

${ }^{24}$ Riedel 1860, s. $138(21,22)$. Zob. Brzustowicz 2009, s. 251-267.

${ }^{25}$ Gahlbeck 2016, s. 106. 
W ramach wypełniania swoich obowiązków uczestniczył m.in. w negocjacjach z margrabią brandenburskim Waldemarem (1304-1319), prowadzonych w Kremmen, w styczniu $1318 \mathrm{r}^{26}$ To on, latem lub jesienią 1318 r., zwołał do Magdeburga pierwszą kapitułę baliwatu, a 12 kwietnia 1319 r. został mianowany przez wielkiego mistrza preceptorem generalnym na obszar Saksonii, Marchii, Turyngii i Słowiańszczyzny ${ }^{27}$.

Powołanie Pawła z Modeny na urząd preceptora generalnego można uznać za początek baliwatu, który nie nazywał się jeszcze baliwatem brandenburskim, lecz był określany za pomocą regionów, jakie obejmował. Ze względu na częste zmiany strukturalne zachodzące w zakonie jego nazwa ulegała pewnym modyfikacjom. Proces ten można prześledzić, analizując tytulatury poszczególnych preceptorów (generalnych). Przykładowo:

1) Paweł z Modeny (1319-1323):

- preceptor domorum Saxonie, Slavie, Thuringie et Marchie ${ }^{28}$,

2) Gebhard von Bortfelde (1323-1336/37):

- Nos frater Ghevehardus de Bortvelde, preceptor generalis sancte domus hospitalis sancti Johannis Jerosolymitani per Saxoniam, Marchiam et Slaviam (Nemerow, 2 kwietnia 1335 r.) ${ }^{29}$,

3) Hermann von Warberg/Werberg (1336/37-1371):

- Hermann von Warberg, Landgebietiger des Johanniterordens in Sachsen, der Mark, Wenden und Pommern (Ueckermünde, 17 czerwca 1345 r. $)^{30}$,

- Broder Herman von Werberg, eyn gemeyne beider in Sassen, in der Marck, in Wentland vnd in Pommern des Ordens des Heiligen Hufes Sancte Johannis Baptisten des Spitahls von Jerusalem (Frankfurt nad Odrą, 21 grudnia 1350 r. $)^{31}$,

- Bruder Herman von Werborge des Ordins des hilgen Huses des Hospits sente Iohannis von Ierusalem, eyn Gemeyne bider In sassen in der Marke, in Wentland und in Pomer (Leśnica, 7 marca 1361 r.) ${ }^{32}$,

${ }^{26}$ Zob. przypis 97.

${ }^{27}$ Gahlbeck 2014, s. 303.

${ }^{28}$ Opgenoorth 1963, s. 38.

${ }^{29}$ Riedel 1860, s. 196 (39).

${ }^{30}$ Urkunden und Regesten zur Geschichte des Johanniterordens 1900, s. 242 (17).

${ }^{31}$ Riedel 1860, s. 134 (17).

${ }^{32}$ Kodeks Dyplomatyczny Wielkopolski: obejmujący dokumenta tak już drukowane, jak dotąd nie ogłoszone, sięgające roku 1400, wydany staraniem Towarzystwa Przyjaciół Nauk Poznańskiego 1879 , s. 178 (1448). 
4) Bernard von der Schulenburg (1371-1392):

- Bruder Bernd Von der Schulenborch, Ordens Sant Johanes des hilgen hufes des hospitals Von Jherusalem, gemeiner gebiediger tu Sassen, tu der Marg, tu Wendland, tu Cassuben vnd in Pomern (Leśnica, 15 stycznia 1392 r. $)^{33}$.

Baliwat nazywano zatem baliwatem Saksonii, Słowiańszczyzny, Turyngii i Marchii (do ok. 1323 r.), następnie Saksonii, Marchii i Słowiańszczyzny, wreszcie Saksonii, Marchii, Słowiańszczyzny i Pomorza. Mianem „brandenburskiego" zaczęto go określać prawdopodobnie w czasach urzędowania mistrza Bernarda von der Schulenburga (1371-1392) ${ }^{34}$. W XV w. używano tej nazwy coraz częściej, a w XVI już regularnie ${ }^{35}$.

W nowo powstałym baliwacie, oprócz wyżej wymienionych domów zakonnych, znalazły się komturie w Goslarze (niem. Goslar, Dolna Saksonia, powiat Goslar) $^{36}$, Wietersheim (obecnie część Petershagen, Nadrenia Północna-Westfalia, powiat Minden-Lübbecke) ${ }^{37}$ i Magdeburgu (Kreuzhof, po templariuszach; Saksonia-Anhalt, miasto na prawach powiatu ${ }^{38}$ oraz siedziby joannitów położone w Turyngii (do ok. $1323 \mathrm{r}$.), które przyłączono do niego zapewne z inicjatywy Pawła z Modeny, będącego komturem w Erfurcie (Turyngia, miasto na prawach powiatu) i Topfstedt (Turyngia, powiat Kyffhäuser) ${ }^{39}$. W struktury baliwatu włączono również domy pomorskie, ulokowane w: Sławnie (niem. Schlawe, woj. zachodniopomorskie, powiat sławieński) ${ }^{40}$, Stargardzie (niem. Stargard in Pommern, woj. zachodniopomorskie, powiat stargardzki) ${ }^{41}$, Suchaniu (niem. Zachan, woj. zachodniopomorskie, powiat stargardzki) ${ }^{42}$, Starogardzie Gdańskim (niem. Preußisch Stargard, woj. pomorskie, powiat starogardzki) ${ }^{43}$, Lubiszewie Tczewskim (niem. Liebschau,

\footnotetext{
${ }^{33}$ Riedel 1863, s. $92-93$ (152).

${ }^{34}$ Riedel 1846, s. 84-86 (1200).

${ }^{35}$ Huschner, Gahlbeck i Szczesiak 2016, s. 317; Joost i in. 2016, s. 281; Joost, Neustadt i Amelung 2016a, s. 404.

${ }^{36}$ Zob. Wilgeroth 2012, s. 519-522.

${ }^{37}$ Zob. Schirmeister 1994, s. 489-493.

${ }^{38}$ Zob. Rödel 1972, s. 430; Kaak 2014, s. 467.

${ }^{39}$ Riedel 1860, s. $128-129$ (8).

${ }^{40}$ Zob. Hoogeweg 1925, s. 869-874, 881-884; Kozłowska 1994, s. 13-15; Wybranowski 1995 , s. 75-92; Smoliński 2008, s. 69-89 i n.; Klassa 2012, s. 78-80; Wybranowski 2016, s. 341-342, 347-352.

${ }^{41}$ Zob. Hoogeweg 1925, s. 870-875, 892-895; Kozłowska 1994, s. 7-10; Majewski 2001, s. 71-80; Wybranowski, 2001, s. 7-40; Smoliński 2008, s. 94, 153, 203, 227, 247; Klassa 2012, s. 74-78; Wybranowski 2016, s. 339-344, 352-355.

${ }^{42}$ Zob. Hoogeweg 1925, s. 885-891; Rödel 1972, s. 441-442; Kozłowska 1994, s. 10-11; Klassa 2012, s. 66, 77, 100, 106; Wybranowski 2016, s. 342-345, 352-355.

${ }^{43}$ Zob. Lange 1994, s. 7-19; Smoliński 1998, s. 221-238; Klassa 2001, s. 15-50; Klassa 2012, s. 81-83.
} 
woj. pomorskie, powiat tczewski) ${ }^{44}$, Skarszewach (niem. Schöneck, woj. pomorskie, powiat starogardzki) ${ }^{45}$ oraz być może w Kopaniu (Copam, Copan, miejsce niezidentyfikowane ${ }^{46}$ i Goleniowie (niem. Gollnow, woj. zachodniopomorskie, powiat goleniowski) ${ }^{47}$.

Niezwykle ważnym momentem dla baliwatu był układ zawarty w Heimbach 11 czerwca 1382 r. pomiędzy preceptorem (generalnym) Bernardem von der Schulenburgiem (Broder Bernth von der Schulenborg, unses vorschreuen Ordens Ballier in der Marcke von Brandenburg) i wielkim przeorem Niemiec, Konradem von Braunsbergiem (Conrad von Brunszberg, Meister Synthe Johans Ordens in Duitzschen Landen). Gwarantował on prezentowanej jednostce organizacyjnej autonomię za cenę 2400 guldenów oraz corocznej opłaty (responsium) ${ }^{48} \mathrm{w}$ wysokości 324 guldenów. Jej przejawem była możliwość wyboru preceptora (generalnego) przez kapitułę, złożoną z lokalnych urzędników zakonnych (głównie komturów), którego następnie zatwierdzał wielki przeor Niemiec. Należy wspomnieć, że autonomia baliwatu była ograniczona. Jego urzędnicy nie mogli prowadzić samodzielnej polityki finansowej. Sprzedaż posiadłości wymagała zgody ze strony zwierzchników z wielkiego przeoratu Niemiec ${ }^{49}$.

\section{BALIWAT U PROGU REFORMACJI}

W przededniu reformacji, w 1517 r., podstawą baliwatu były posiadłości leżące w Marchii Brandenburskiej, Księstwie Meklemburgii i Księstwie Pomorskim:

1) Marchia Brandenburska:

- komturia w Chwarszczanach (niem. Quartschen, woj. zachodniopomorskie, powiat myśliborski) ${ }^{50}$,

${ }^{44}$ Zob. Lange 1994, s. 7-19; Smoliński 1998, s. 221-238; Klassa 2012, s. 81-83, 106, 126-127.

${ }^{45}$ Zob. Waschinski 1904; Milewska 1993, s. 141-153; Lange 1994, s. 7-19; Klassa 2012, s. 66, 81-82, 106, 113-114.

${ }^{46}$ Komturię przed 1295 r. przeniesiono do Suchania. Możliwe jednak, że w Kopaniu pozostała niewielka grupa braci zakonnych do ok. 1324/1325 r. Zob. Starnawska 1991, s. 26; Smoliński 2008, s. 78, 239, 247, 254; Klassa 2012, s. 66, 75, 77-78, 100; Wybranowski 2016, s 342-344.

${ }^{47}$ Komturia w Goleniowie powstała ok. 1291 r. na gruncie nadań książęcych z lat 1287-1291. Nie wiadomo, czy funkcjonowała w momencie utworzenia baliwatu, choć joannici byli w posiadaniu części posiadłości, które stanowiły jej uposażenie aż do 1361 r. Zob. Wybranowski 1999, s. 9-23.

${ }^{48}$ Zob. Sire 2000, s. 166; King 2016, s. 91.

${ }^{49}$ Riedel 1846, s. 84-86 (1200). Zob. Opgenoorth 1963, s. 43-44; Lange 1999, s. 102; Starnawska 1999, s. 72; Starnawska 2000, s. 19-20; Floto 2003, s. 43-44.

${ }^{50}$ Zob. przypis 13 . 
- komturia w Golicach (niem. Grüneberg, woj. zachodniopomorskie, powiat gryfiński ${ }^{51}$,

- komturia w Leśnicy (niem. Lietzen, Brandenburgia, powiat Märkisch-Oderland) ${ }^{52}$,

- komturia w Łagowie (niem. Lagow, woj. lubuskie, powiat świebodziński $)^{53}$,

- komturia w Werben (Saksonia-Anhalt, powiat Stendal) ${ }^{54}$,

- przeorat w Lychen (Brandenburgia, powiat Uckermark) ${ }^{55}$.

2) Księstwo Meklemburgii:

- przeorat w Groß Eichsen (Meklemburgia-Pomorze Przednie, powiat Nordwestmecklenburg $)^{56}$,

- komturia Kraak (Meklemburgia-Pomorze Przednie, powiat Ludwigslust-Parchim $)^{57}$,

- komturia Mirow (Meklemburgia-Pomorze Przednie, powiat Mecklenburgische Seenplatte $)^{58}$,

- komturia Nemerow (Meklemburgia-Pomorze Przednie, powiat Mecklenburgische Seenplatte) ${ }^{59}$.

3) Księstwo Pomorskie:

- komturia w Swobnicy (niem. Wildenbruch, woj. zachodniopomorskie, powiat gryfiński) ${ }^{60}$,

- komturia w Suchaniu (niem. Zachan, woj. zachodniopomorskie, powiat stargardzki) ${ }^{61}$,

- komturia w Kolinie (niem. Kollin, woj. zachodniopomorskie, powiat stargardzki $)^{62}$.

${ }^{51}$ Zob. Gahlbeck 2007b, s. 551-558; Rymar 2012, s. 183-190; Gahlbeck 2013, s. 149-160; Rymar 2015, s. 839-840.

${ }^{52}$ Zob. przypis 15.

${ }^{53}$ Zob. Przybył 2006, s. 395-404; Gahlbeck 2007c, s. 723-743; Wasilkiewicz 2016a, s. 195-212.

${ }^{54}$ Zob. przypis 3.

${ }^{55}$ Przeorat funkcjonował przynajmniej do $1381 \mathrm{r}$. Jak długo potem, tego nie wiemy, ale możliwe, że nawet do lat 30. XVI w. Herrenmeister Wit von Thümen (1527-1544) przekazał miastu Lychen prawa do wyboru tamtejszego proboszcza dopiero 25 stycznia 1533 r. Zob. Gahlbeck, Huschner i Schumann 2014, s. 431-441.

${ }^{56}$ Zob. przypis 4.

${ }^{57}$ Zob. przypis 5.

${ }^{58}$ Zob. przypis 6.

${ }^{59}$ Zob. przypis 8.

${ }^{60}$ Zob. Hoogeweg 1925, s. 898-904; Rödel 1972, s. 440-441; Radacki 1976, s. 138-147; Radacki 2005/2006, s. 9-12; Hein 2009, s. 152-173.

${ }^{61}$ Zob. przypis 42.

${ }^{62}$ Zob. Hoogeweg 1925, s. 871, 886-887; Rödel 1972, s. 425; Rymar 2003, s. 49-70. 
Ponadto należały do niego m.in. komturie w Süpplingenburgu (Dolna Saksonia, powiat Helmstedt) ${ }^{63}$ i Wietersheim (obecnie część Petershagen, Nadrenia Północna-Westfalia, powiat Minden-Lübbecke) ${ }^{64}$ oraz przeorat w Brunszwiku (niem. Braunschweig, Dolna Saksonia, miasto na prawach powiatu $)^{65}$.

Prawidłowe funkcjonowanie podstawowych jednostek organizacyjnych było bardzo ważne dla baliwatu. Komturie, często doskonale uposażone, stanowiły główne źródło utrzymania administracji zakonnej. Na ich czele stali komturzy (komandorzy), pochodzący zazwyczaj $\mathrm{z}$ rodów szlacheckich z Brandenburgii, Meklemburgii, Pomorza Zachodniego i Dolnej Saksonii ${ }^{66}$. To oni reprezentowali zakon na gruncie lokalnym, odpowiadając za relacje z otoczeniem społecznym. Przewodzili miejscowemu konwentowi, dbając o przestrzeganie zakonnej reguły. Zarządzali posiadłościami, które należały do komturii6 ${ }^{67}$.

W baliwacie wykształciły się również przeoraty, których jednak nie należy mylić z nadrzędnymi wobec niego jednostkami administracyjnymi. Były to domy zakonne, skupiające braci-kapelanów, kierowane przez kapłana tytułowanego przeorem, którym podlegały poszczególne kościoły parafialne ${ }^{68}$. $\mathrm{W}$ baliwacie, w przededniu reformacji, istniały co najmniej dwa przeoraty w Groß Eichsen i Brunszwiku ${ }^{69}$. Status domu zakonnego w Lychen, w świetle zachowanych źródeł, pozostaje niewyjaśniony ${ }^{70}$.

Ważną rolę $\mathrm{w}$ baliwacie odgrywały kościoły parafialne. Były to idealne miejsca do prowadzenia polityki, pozyskiwania środków na realizację zakonnych przedsięwzięć i, co oczywiste, do sprawowania działalności duszpasterskiej, do której jednak joannici w XVI stuleciu przywiązywali mniejszą wagę niż $\mathrm{w}$ wiekach wcześniejszych. Pod patronatem szpitalników pozostawał szereg miejskich kościołów parafialnych, znajdujących się m.in. w: Chojnie (niem. Königsberg in der Neumark, woj. zachodniopomorskie, powiat gryfiński), Choszcznie (niem. Arnswalde, woj. zachodniopomorskie, powiat choszczeński), Lychen, Łagowie, Sławnie, Słońsku (niem. Sonnenburg, woj. lubuskie, powiat sulęciński), Sulęcinie, Stargardzie i Werben oraz liczne

\footnotetext{
${ }^{63}$ Zob. przypis 21.

${ }^{64}$ Zob. przypis 37.

${ }^{65}$ Zob. Steinführer 2012a, s. 138-141.

${ }^{66}$ Starnawska 1992, s. 19-20.

${ }^{67}$ Nicholson 2001, s. 79-80. Zob. Sawicki 2004, s. 154.

${ }^{68}$ Zob. King 2016, s. 85.

${ }^{69}$ Steinführer 2012a, s. 138-141; Joost i in. 2016, s. 281, 283, 285.

${ }^{70}$ Zob. przypis 55 .
} 
kościoły wiejskie położone w miejscowościach należących do poszczególnych komturii, w których posługę sprawowali głównie duchowni diecezjalni ${ }^{71}$.

Zwierzchnikiem wszystkich joannitów na obszarze baliwatu był mistrz, określany w średniowiecznych dokumentach preceptorem (najczęściej generalnym) albo baliwem, a od czasów reformacji herrenmeistrem ${ }^{72}$. Początkowo był on urzędnikiem mianowanym przez kierownictwo zakonu, ale zmieniło się to na skutek układu w Heimbach (11 czerwca 1382 r.). Od tego momentu, o czym już wspomniano, wybierała go kapituła baliwatu, złożona z lokalnych komturów i ewentualnie przeorów, a następnie zatwierdzał mistrz wielkiego przeoratu Niemiec ${ }^{73}$.

Preceptorzy (generalni) pochodzili głównie z brandenburskiej i pomorskiej szlachty, dla której przynależność do joannitów była nobilitująca i dawała szansę na zrobienie kariery w zakonnych strukturach. Wśród mistrzów baliwatu znajdowali się m.in. przedstawiciele rodów von der Schulenburg (Bernard w latach 1371?/1376-1392 i Ryszard w latach 1474-1491), von Güntersberg (Reimar w latach 1399-1418 i Kacper w latach 1471-1474) czy von Schlieben (Baltazar w latach 1426-1437 i Liboriusz w latach 1460-1471). W przededniu reformacji urząd preceptora (generalnego) sprawował Jerzy von Schlabrendorff (1491-1526) ${ }^{74}$.

Mistrzowie baliwatu w wyniku układu w Heimbach (11 czerwca 1382 r.) uzyskali dużą samodzielność $\mathrm{w}$ zakresie prowadzenia polityki. Osadzeni w konkretnych realiach społecznych, podejmowali współpracę z władcami i miejscowymi rodami szlacheckimi na gruncie dyplomatycznym, gospodarczym, finansowym i wojskowym. Podstawę ich funkcjonowania stanowiły fundusze wypłacane ze skarbca baliwatu (w XV w. 200 kop groszy praskich rocznie $)^{75}$, renty naturalne ${ }^{76}$, a od XV w. również dobra uzyskiwane z posiadłości kameralnych (urzędów domenalnych) - kompleksów ziemskich, nadzorowanych przez wyznaczonych do tego celu zarządców, z których tuż przed reformacją dwa istniały na ziemi lubuskiej, administrowane ze Słońska i Rąpic (niem. Rampitz, woj. lubuskie, powiat słubicki) ${ }^{77}$, dwa zaś prawdopo-

${ }^{71}$ Starnawska 1992, s. 16-17; Gahlbeck 2017a, s. 112-120.

${ }^{72}$ Sarnowsky 2001, s. 175.

${ }^{73}$ Riedel 1846, s. 84-86 (1200). Zob. von Winterfeld 1859, s. 776.

${ }^{74}$ von Mackensen-Astfeld 1977, s. 630; Starnawska 1992, s. 20; Lange 1999, s. 107-108.

${ }^{75}$ Gahlbeck, Gebuhr i Schumann 2007, s. 1156.

${ }^{76} \mathrm{~Np}$. obowiązek parafii Marxdorf do corocznej opłaty 7 wispli owsa na rzecz mistrza baliwatu brandenburskiego joannitów, Brandenburgisches Landeshauptarchiv in Potsdam, Rep. 9B, Johanniterorden, $\mathrm{nr} 7764$.

${ }^{77}$ Zob. von Dellingshausen 2011, s. 38-40; Wasilkiewicz 2016b, s. 59-73. 
dobnie na Dolnych Łużycach, skupione wokół Sękowic (niem. Schenkendorf, woj. lubuskie, powiat krośnieński) i Friedlandu (Brandenburgia, powiat Oder-Spree $)^{78}$.

Do czasów reformacji preceptorzy (generalni) nie mieli stałej siedziby. Rezydowali na zamkach i dworach zakonnych położonych w różnych częściach baliwatu. Według ustaleń Christiana Gahlbecka w latach 1323-1527 przez dłuższy czas przebywali w pięciu lub sześciu ośrodkach - Brunszwiku, Süpplingenburgu, Swobnicy, Łagowie, Słońsku i być może w Gartow (Dolna Saksonia, powiat Lüchow-Dannenberg). Na krótko ich rezydencjami były również Suchań i Werben ${ }^{79}$. W latach 40. XVI w. wskutek działań margrabiego Jana z Kostrzyna (1535-1571) główną siedzibą mistrzów i ośrodkiem administracji baliwatu został Słońsk ${ }^{80}$.

\section{BALIWAT W DOBIE REFORMACJI}

Reformacja wywarła silny wpływ na funkcjonowanie baliwatu brandenburskiego. Jego posiadłości stały się łakomym kąskiem dla władców, których pozycja względem instytucji kościelnych wyraźnie wzrosła. W Meklemburgii książę Jan Albrecht I doprowadził do sekularyzacji komturii w Kraak (w 1547 r. $)^{81}$ i przeoratu w Groß Eichsen (w 1552 r. $)^{82}$, a na urząd komtura w Nemerow mianował, bez konsultacji z herrenmeistrem Tomaszem von Rungem (1545-1564), swojego radcę dworu, Joachima von Holsteina (w 1552 r. $)^{83}$. Zresztą tamtejsi książęta ingerowali w wewnętrzne sprawy baliwatu już wcześniej. W latach 20. XVI w. Henryk V i Albrecht VII podjęli próbę podporządkowania sobie komturii w Mirow, wysuwając na urząd komtura kandydaturę swojego protegowanego, Jerzego Rabego. Joannici zdecydowanie wystąpili przeciwko ich działaniom na gruncie dyplomatycznym. Poprosili o interwencję elektora brandenburskiego Joachima I, margrabiego brandenburskiego Joachima II oraz książąt pomorskich, Jerzego I i Barnima IX. Wskutek ich zabiegów władcy Meklemburgii ustąpili, a her-

\footnotetext{
${ }^{78}$ Zob. Rödel 1972, s. 426, 434; Gahlbeck, Gebuhr i Schumann 2007, s. 1155, 1172; von Dellingshausen 2011, s. 41.

${ }^{79}$ Gahlbeck 2014, s. 319.

${ }^{80}$ Kaak 2014, s. 470. Zob. Radacki 1976, s. 153-158; Nekanda-Trepka 2004, s. 161-172; Radacki 2005/2006, s. 12-16; Schumann 2006, s. 49-66; Gahlbeck, Gebuhr i Schumann 2007, s. 1148-1173; Hein 2009, s. 104-134; Skaziński 2011, s. 11-35; Jager 2014, s. 521-539.

${ }^{81}$ Joost, Neustadt i Amelung 2016a, s. 404, 407.

82 Joost i in. 2016, s. 281, 283.

${ }^{83}$ Huschner, Szczesiak i Gahlbeck 2016, s. 544, 550.
} 
renmeister Wit von Thümen (1527-1544), w styczniu 1528 r., mianował komturem Mirow Liboriusza von Bredowa ${ }^{84}$.

Niebezpieczeństwo utraty komturii zostało zażegnane, ale jedynie tymczasowo. Po śmierci mistrza von Bredowa, do której doszło w styczniu $1541 \mathrm{r}^{85}$, Henryk V i Albrecht VII pomogli ją przejąć księciu Wilhelmowi von Braunschweigowi-Lüneburgowi ${ }^{86}$. Komtur Mirow, Zygmunt von der Marwitz, po niespełna trzech miesiącach sprawowania urzędu, został zmuszony w marcu 1541 r. do opuszczenia swojej siedziby (tytuł zachował do 1546 r.) ${ }^{87}$. Joannici utracili wówczas wpływ na funkcjonowanie komturii, która oficjalnie została zlikwidowana dopiero $\mathrm{w}$ wyniku postanowień pokoju westfalskiego, w październiku $1648 \mathrm{r}^{88}$

Do poważnego konfliktu z udziałem szpitalników doszło w latach 40 . XVI w. na Pomorzu, gdzie książę wołogoski Filip I postanowił podporządkować sobie komturię w Swobnicy. Po śmierci tamtejszego mistrza, Gotszalka von Veltheima (w 1544 r.), wyznaczył na urząd komtura swojego kanclerza, Baltazara von Waldowa. Joannici nie zaakceptowali tej kandydatury. Wybrali na komtura Baltazara von der Marwitza. Książę uznał ich działania za przejaw buntu i wysłał do Swobnicy oddział zbrojnych ${ }^{89}$. Wobec tak silnego przejawu agresji baliwat mógł podjąć jedynie akcję dyplomatyczną, która przez długi czas nie przynosiła zdecydowanych efektów. Strony doszły do porozumienia dopiero 27 września $1547 \mathrm{r}$. Wówczas herrenmeister Tomasz von Runge (1545-1564) zawarł z Filipem I układ w Wołogoszczy (niem. Wolgast, Meklemburgia-Pomorze Przednie, powiat Vorpommern-Greifswald), na mocy którego komturia w Swobnicy pozostała przy joannitach, ale zarządzać nią mógł jedynie pochodzący z Pomorza luteranin, którego kandydatura została zaakceptowana przez księcia. Ustalono, że komturem swobnickim będzie doradca książęcy, doktor praw, Andrzej von Blumenthal. Mistrz Tomasz von Runge (1545-1564) złożył władcy hołd i obiecał wypełniać wszelkie obowiązki lenne ${ }^{90}$.

Sprawa komturii w Swobnicy nie była jedynym problemem, jaki dotknął joannitów na Pomorzu. W 1544 r. książę szczeciński Barnim IX zajął siedzibę

\footnotetext{
${ }^{84}$ Gahlbeck, Holst i Szczesiak 2014, s. 491-492; Szczesiak i Gahlbeck 2014, s. 211, 214; Gahlbeck 2017b, s. 147.

${ }^{85}$ Szczesiak i Gahlbeck 2014, s. 211.

${ }^{86}$ Gahlbeck 2017b, s. 147.

${ }^{87}$ Szczesiak i Gahlbeck 2014, s. 211.

${ }^{88}$ Gahlbeck, Holst i Szczesiak 2014, s. 482.

${ }^{89}$ Rödel 1972, s. 441; Hein 2009, s. 157-158.

${ }^{90}$ Riedel 1858, s. 493-496 (2586). Zob. Sarnowsky 2006, s. 133-134.
} 
zakonną w Suchaniu ${ }^{91}$. Kapituła baliwatu zdecydowała się wówczas na sprzedaż komturii jego marszałkowi dworu, Wolfowi z rodu Borków (von Borcke), za cenę 24000 florenów. Do transakcji doszło w styczniu 1545 r. ${ }^{92}$ i to pomimo protestów ze strony wielkiego przeora Niemiec Jana von Hattsteina $(1512-1546)^{93}$, który na mocy układu w Heimbach (11 czerwca 1382 r.) powinien zatwierdzić sprzedaż komturiii ${ }^{94}$. W 1551 r. prawa do Suchania przeszły na księcia Barnima IX ${ }^{95}$.

Kluczowe dla joannitów były relacje $\mathrm{z}$ władcami Brandenburgii. W literaturze przedmiotu wielokrotnie podkreślano ich prawa względem baliwatu, wśród których wymieniano:

1) prawo patronatu nad baliwatem,

2) prawo do nominacji preceptora (generalnego)/herrenmeistra,

3) prawo do prezentacji preceptora (generalnego)/herrenmeistra,

4) prawo do nominacji komturów ${ }^{96}$.

Proces kształtowania tych prerogatyw zapoczątkował układ z Kremmen, zawarty 29 stycznia $1318 \mathrm{r}$. pomiędzy margrabią Waldemarem z dynastii askańskiej i zakonem joannitów, reprezentowanym przez Pawła z Modeny oraz Leonarda von Tybertisa. Porozumienie regulowało kwestię własności dóbr należących uprzednio do templariuszy, które znajdowały się na obszarze Marchii Brandenburskiej (m.in. Sulęcina, Długoszyna, Brzeźna, Rychlika, Grabna i Lubowa). Z treści układu wynika, że margrabia przyjął rolę protektora, obiecując joannitom swoją opiekę i pomoc ${ }^{97}$.

Przełomowa w kontekście niniejszych rozważań była dyrektywa króla niemieckiego Zygmunta Luksemburskiego z 9 maja 1415 r. Władca nakazał wówczas preceptorowi (generalnemu) Reimarowi von Güntersbergowi (1399-1418) złożyć hołd lenny nowemu elektorowi i margrabiemu brandenburskiemu, Fryderykowi I Hohenzollernowi (1415-1440) ${ }^{98}$. Akt zdecydowanie osłabił pozycję mistrza względem panującego. Sprawił, że zwierzchnik

\footnotetext{
${ }^{91}$ Rödel 1972, s. 442; Sarnowsky 2006, s. 132.

${ }^{92}$ Riedel 1863, s. 246 (307).

${ }^{93}$ Rödel 1972, s. 442.

${ }^{94}$ Riedel 1846, s. 84-86 (1200).

${ }^{95}$ Hoogeweg 1925, s. 895.

${ }^{96}$ Opgenoorth 1963, s. 56-59; Rödel 1972, s. 418; Schultze 1989b, s. 104-105; von Campenhausen 1990, s. 40-41; Schmook 2005, s. 48-49.

${ }_{97}$ Riedel 1860, s. 128-129 (8); Heinemann 1905, s. 365-366 (3166). Zob. Floto 2003, s. 41-43; Brzustowicz 2009, s. 258-261.

${ }^{98}$ Zygmunt Luksemburski nakazuje mistrzowi baliwatu złożyć hołd lenny Fryderykowi Hohenzollernowi, Brandenburgisches Landeshauptarchiv in Potsdam, Rep. 9B, Johanniterorden U. 218 .
} 
ponadregionalnej, zakonnej jednostki organizacyjnej popadł w zależność od elektora brandenburskiego ${ }^{99}$.

Pomimo tego rządzący aż do lat 30 . XVI w. ingerowali w wewnętrzne sprawy baliwatu $\mathrm{w}$ sposób marginalny ${ }^{100}$. Odmienne podejście cechowało dopiero Jana z Kostrzyna (1535-1571) - od 1535 r. władcę Nowej Marchii, ziemi torzymskiej, księstwa krośnieńskiego, Sulechowa, Lubska z ziemią bobrowiecką oraz okręgów Cottbus i Peitz ${ }^{101}$. Margrabia uznał, że herrenmeister Wit von Thümen (1527-1544) jako pan Słońska jest jego poddanym, od którego można i należy wymagać posłuszeństwa. Siebie natomiast uważał za patrona baliwatu, powołując się na dawne tradycje łączące joannitów z domem Hohenzollernów, choć formalnie został nim w 1544 r. ${ }^{102}$

Należy dodać, że stosunek Jana z Kostrzyna wobec joannitów ewoluował. Margrabia, po dokonaniu konwersji na luteranizm (na Wielkanoc 1538 r.) ${ }^{103}$, rozpatrywał sekularyzację baliwatu lub posiadłości szpitalników, które znajdowały się w jego państwie. Potwierdza to list, napisany przez niego na początku 1539 r., którego adresatem był doktor Konrad Mertsch, doradca Jana, przebywający wówczas we Frankfurcie nad Menem ze względu na obrady Związku Szmalkaldzkiego:

Szczere pozdrowienia. Nie chcemy ukrywać przed wami naszego stanowiska. Po wprowadzeniu dzięki łasce opatrzności nabożeństw ewangelickich, które teraz są odprawiane $\mathrm{w}$ zgodzie $\mathrm{z}$ treścią Pisma, dla utrzymania karności i zachowania porządku przeprowadziliśmy $\mathrm{w}$ naszym księstwie wizytację. Stwierdziliśmy, że w księstwie naszym i na terenach okolicznych swoje dobra posiada jeszcze zakon joannitów $\mathrm{z}$ siedzibą $\mathrm{w}$ Torzymiu ${ }^{104}$. W ich posiadaniu, co stwierdzamy, znajdują się również nie leżące na naszym terenie dobra. Ponadto na naszym terytorium znajdują się majętności biskupa lubuskiego oraz kapituły w Fürstenwalde. Jest to wiele wsi leżących koło Torzymia. W majątkach tych nie wprowadzono jeszcze nowego porządku kościelnego ani nie odprawia się właściwych ceremonii. Ponieważ naszym zamiarem jest utrzymać zgodę i jedność w naszym kraju oraz dać wolność słowu, dlatego przedkładamy tę sprawę we Frankfurcie nad Menem, przed książętami zebranymi z powodu religii. Prosimy Waszą Miłość o poddanie rozwadze tej sprawy i zrozumienie, jak to jest, gdy kilku duchownych i religijne bractwo znajduje się pod władzą Waszej Miłości, a inni, którzy nie przynależą Waszej Miłości, mają dobra w tym kraju. I czy wspomniani mistrz joannitów, biskup lubuski i kapituła w Fürstenwalde mogą wzbraniać się przed przyjęciem porządku kościelnego, który my chcemy im pokazać? Nie tylko nie pozwalają słowu swobodnie roz-

\footnotetext{
${ }^{99}$ Kaak 2014, s. 471. Zob. Floto 2003, s. 44-46.

${ }^{100}$ Zob. Gahlbeck 2017a, s. 126-128.

${ }^{101}$ Schultze 1989a, s. 227; Wachowiak i Kamieński 2001, s. 246; Vogel 2006, s. 85.

102 Gahlbeck 2017a, s. 128.

${ }^{103}$ Kletke 1876, s. 84 i n.; Gahlbeck 2017c, s. 235-236.

104 Torzym (niem. Sternberg, woj. lubuskie, powiat sulęciński) nie należał w tym czasie do zakonu joannitów, ale do rodziny von Winningów. Zob. Wohlbrück 1832, s. 466.
} 


\begin{abstract}
brzmiewać, lecz nie poprzestając na tym, innym w tej niedorzeczności pomagają, tak by i oni nie mogli poznać prawdziwego oblicza Pana. Najbardziej więc przykładamy się do tego, by nie posądzono nas, że zbyt mało, lecz by uznano, że czynimy wiele w tej sprawie. Wasza Miłość rozważy to i doniesie nam łaskawie, jaką pisemną otrzymamy zaskarbiwszy sobie łaskę Waszej Miłości, oraz wskaże, co czynić w tej sprawie powinniśmy ${ }^{105}$.
\end{abstract}

Margrabia zmienił plany wobec joannitów prawdopodobnie na początku lat 40. XVI w. Dostrzegł wówczas możliwości finansowego i politycznego wykorzystania baliwatu. W jego ponadregionalnych strukturach zobaczył szansę na rozszerzenie swojej władzy poza granice Nowej Marchii. Roztoczenie kurateli nad poszczególnymi komturiami dawało wszak nadzieję na możliwość ingerencji w wewnętrzne sprawy sąsiednich państw. W administracji baliwatu margrabia widział przestrzeń dla swoich protegowanych. Urzędy zakonne nadal cieszyły się społecznym szacunkiem, a ich sprawowanie postrzegano jako nobilitację. Jan z Kostrzyna (1535-1571) stał się prawdopodobnie jedynym władcą, któremu zależało na tym, aby baliwat przetrwał reformację. Książęta meklemburscy, brunszwiccy czy pomorscy planowali zsekularyzować posiadłości zakonne i włączyć je do swoich domen ${ }^{106}$.

Dla baliwatu ceną przetrwania był wzrost zależności od margrabiego, który skrzętnie wykorzystywał swoją pozycję. W czerwcu 1540 r. wymusił na joannitach zamianę komturii chwarszczańskiej na posiadłości świdwińskie (układ w Kostrzynie nad Odrą, 15 czerwca 1540 r.). Pozyskał w ten sposób rozległy kompleks ziemski z doskonale funkcjonującymi gospodarstwami, które już od lat 30. XVI w. zaopatrywały jego dwór w produkty rolne. Nowo powstały urząd komtura w Świdwinie (niem. Schivelbein, woj. zachodniopomorskie, powiat świdwiński) został połączony z urzędem landwójta, co $\mathrm{z}$ jednej strony podnosiło jego status, $\mathrm{z}$ drugiej jednak podporządkowywało go margrabiemu ${ }^{107}$.

Jan z Kostrzyna (1535-1571) szczególnie silny wpływ na wewnętrzne sprawy baliwatu uzyskał wiosną 1544 r. po śmierci mistrza Wita von Thümena (1527-1544) ${ }^{108}$. Udało mu się wówczas narzucić swoją wolę kapitule, która zebrała się w Słońsku i 20 czerwca 1544 r. wynieść na urząd herrenmeistra Joachima von Arnima (1544-1545) ${ }^{109}$. Była to prawdopodobnie pierwsza

\footnotetext{
${ }^{105}$ Cyt. za: Konopnicka-Szatarska 2001, s. 171-172. Zob. Riedel 1861, s. 327 (194).

${ }^{106}$ Schmook 2005, s. 48; Gahlbeck 2017a, s. 131.

${ }^{107}$ Riedel 1859, s. 277-279 (83); Riedel 1863, s. 246 (307); Kletke 1876, s. 98-99. Zob. Dolański i Konopnicka-Szatarska 2001, s. 77-78; Rymar 2002, s. 33-34; Gahlbeck i Schumann 2007, s. 998-999; Kaak 2014, s. 472-473.

${ }^{108}$ Riedel 1863, s. 242 (306); Kletke 1876, s. 114.

${ }^{109}$ Riedel 1863, s. 242 (306); Kletke 1876, s. 114-115.
} 
w dziejach baliwatu elekcja przeprowadzona pod dyktando osoby spoza zakonu $^{110}$. Margrabia decydował również o wyborze kolejnych mistrzów: Tomasza von Rungego (1545-1564) w kwietniu 1545 r. ${ }^{111}$, Franciszka von Neumanna (1564-1568) w kwietniu 1564 r. ${ }^{12}$ i Marcina von Hohensteina (1569-1609) w styczniu 1569 r. ${ }^{113}$ Dominującą pozycję względem baliwatu, pomimo przejściowych trudności (np. konfliktu z Franciszkiem von Neumannem $)^{114}$, utrzymał do ostatnich dni swojego panowania. Zmarł w Kostrzynie nad Odrą 13 stycznia 1571 r. $^{115}$

Wszyscy mistrzowie, którzy objęli urząd dzięki Janowi z Kostrzyna (1535-1571), byli luteranami. Ich mianowanie wpisywało się $\mathrm{w}$ długotrwały proces protestantyzacji baliwatu, zapoczątkowany w latach 20. XVI w. ${ }^{116}$ Zmiany zachodzące wskutek reformacji, tłumione na obszarze Marchii Brandenburskiej przez elektora Joachima I (1499-1535) ${ }^{117}$, dostrzegał już preceptor (generalny) Jerzy von Schlabrendorff (1491-1526). Tuż przed śmiercią, w grudniu 1526 r., napomniał komturów i braci zakonnych, aby zachowali jedność, dbali o swoją wspólnotę, bronili zakonu, miłowali współbraci, a swojego przyszłego mistrza poważali i byli mu posłuszni. Ponadto prosił ich, by pozostali wierni Bogu Wszechmogącemu i jego Królestwu, zachowali szacunek wobec kapłanów i nie zapominali o ubogich, wdowach i sierotach ${ }^{118}$.

Jego następcy, Witowi von Thümenowi (1527-1544), przyszło zmierzyć się z licznymi wyzwaniami. Po pierwsze był zmuszony bronić posiadłości zakonnych przed przejęciem ich przez książąt pomorskich, meklemburskich i brunszwickich. Po drugie musiał przeciwstawić się margrabiemu brandenburskiemu Janowi z Kostrzyna (1535-1571), który pod koniec lat 30. XVI w. rozpatrywał sekularyzację baliwatu. Po trzecie był zobligowany do stałej współpracy z owym margrabią, co było trudne i wymagało od niego dużej elastyczności. Po czwarte jego obowiązkiem było rozwiązywanie bieżących problemów, które dotykały baliwat, takich jak nieprzestrzeganie reguły przez członków zakonu czy utrzymanie kościołów parafialnych pozostających pod

\footnotetext{
${ }^{110}$ Gahlbeck 2017a, s. 126-127.

${ }^{111}$ Riedel 1863, s. 243-245 (306); Kletke 1876, s. 119-120.

${ }_{112}$ Riedel 1863, s. 247 (307); Kletke 1876, s. 364.

${ }^{113}$ Riedel 1863, s. 248 (307); Kletke 1876, s. 406.

114 Zob. Opgenoorth 1963, s. 127-143; Dolański i Konopnicka-Szatarska 2001, s. 79-80; Wasilkiewicz 2016a, s. 218-219.

${ }^{115}$ Kletke 1876, s. 428; Mollwo 1926, s. 580; Dzwonkowski 1998, s. 102.

${ }_{116}$ Zob. Floto 2003, s. 46-50.

117 Zob. Wachowiak i Kamieński 2001, s. 173-176.

${ }^{118}$ Riedel 1863, s. 239 (306). Zob. Opgenoorth 1963, s. 61-62.
} 
patronatem joannitów. Po piąte jego powinnością było ustosunkowanie się do reformacji oraz podjęcie decyzji w sprawie dokonywania przez braci zakonnych konwersji na luteranizm i zawierania przez nich małżeństw ${ }^{119}$.

Wit von Thümen (1527-1544) prowadził politykę realną. Wiedział, że nie powstrzyma zmian, które przyniosła reformacja, zwłaszcza po śmierci elektora Joachima I (11 lipca 1535 r.) ${ }^{120}$. Pozwolił zatem luterańskim kaznodziejom na prowadzenie ewangelizacji i odprawianie nabożeństw w miejscowościach związanych z joannitami, m.in. w Słońsku, Werben, Chojnie, Choszcznie, Łagowie i Sulęcinie, a braciom zakonnym na zmianę wyznania ${ }^{121}$. Symboliczny wymiar miało zwłaszcza powołanie przez niego Jana Jakobitza pastorem w Słońsku i przekazanie mu tamtejszej parafii w $1538 \mathrm{r} .{ }^{122}$ Mistrz wyraził również zgodę na przeprowadzenie wizytacji w majątkach zakonnych, które zostały zarządzone w Nowej Marchii przez Jana z Kostrzyna (1535-1571) a w Marchii Elektorskiej przez Joachima II (1535-1571). Zaakceptował także nowe ordynacje kościelne wprowadzone przez władców w 1540 r. ${ }^{123}$

Postawa Wita von Thümena (1527-1544) z jednej strony zapewniła baliwatowi przetrwanie, $\mathrm{z}$ drugiej jednak przyczyniła się do zmiany jego charakteru z katolickiego na protestancki, co niosło za sobą szereg konsekwencji. Przykładowo, joannici utracili wpływy w wielu kościołach parafialnych. Pozbawiło ich to sporych dochodów i było jedną z przyczyn zaniku księży zakonnych w baliwacie w II połowie XVI w. Brak kapelanów uniemożliwił im z kolei na prowadzenie działalności duszpasterskiej, którą zajęli się głównie pastorzy ewangeliccy ${ }^{124}$.

Należy również wspomnieć o zmianach, które dotknęły komturie na skutek zawierania małżeństw przez członków zgromadzenia. Wit von Thümen (1527-1544) godził się na nie wbrew zaleceniom wielkiego przeora Niemiec, Jana von Hattsteina (1512-1546), który doradził mistrzowi baliwatu, aby pozbawił on urzędów wszystkich braci, którzy nie przestrzegali zakonnych statutów, a w razie sprzeciwu $\mathrm{z}$ ich strony wystąpił przeciwko nim przed Sądem Kameralnym Rzeszy ${ }^{125}$. Pierwszym żonatym komturem był prawdopodobnie Liboriusz von Bredow, zwierzchnik joannitów w Mirow, w Meklemburgii,

\footnotetext{
${ }^{119}$ von Winterfeld 1859 , s. 705-708.

${ }^{120}$ Kletke 1876, s. 32; Schultze 1989a, s. 226.

${ }^{121}$ Gahlbeck 2017a, s. 114 i n.

122 Spieker 1839, s. 138-139; Schilling i Stege 2012, s. 37; Gahlbeck 2017c, s. 254.

${ }^{123}$ Zob. Wachowiak i Kamieński 2001, s. 179-182.

${ }^{124}$ Gahlbeck 2017a, s. 120-121.

${ }^{125}$ Sarnowsky 2006, s. 130.
} 
w latach 1528-1541 ${ }^{126}$, który wziął ślub najpóźniej w 1527 r. ${ }^{127}$ Za jego przykładem podążyli inni. We wtorek 6 czerwca 1542 r. zeswatano komtura Świdwina Melchiora von Barfussa z Esterą von Damitz ${ }^{128}$. W 1543 r., będąc już po ślubie, brał on udział w obradach kapituły baliwatu, obok dwóch innych żonatych komturów - Andrzeja von Schliebena $z$ Łagowa i Aschwina von Cramma $\mathrm{z}$ Nemerow ${ }^{129}$. Zwierzchnicy $\mathrm{z}$ wielkiego przeoratu Niemiec byli bezradni wobec atrakcyjności nowego modelu życia. W 1544 r. podczas kapituły prowincjalnej zdecydowali się na nadanie praw do zawierania małżeństw braciom $\mathrm{z}$ baliwatu brandenburskiego ${ }^{130}$.

Pojawienie się w zakonnych siedzibach kobiet, a z czasem również dzieci, wymagało wprowadzenia nowych rozwiązań. Poszczególne pokoje zostały przystosowane do ich potrzeb ${ }^{131}$. Prawdopodobnie zatrudniono wówczas dodatkowe osoby w charakterze służby. Komturzy wywodzili się przecież ze znamienitych rodów szlacheckich. Ich rodziny musiały żyć na odpowiednim poziomie. Zmiany obyczajów szły w parze z zanikiem życia konwentualnego w komturiach i przyczyniły się do tego, że joannici z baliwatu brandenburskiego zaczęli przypominać bractwo rycerskie lub, jak stwierdziła Maria Starnawska, zsekularyzowane stowarzyszenie rycerzy ${ }^{132}$.

Protestantyzacji baliwatu próbowała przeciwdziałać centrala zakonu z Malty. W 1551 r. nakazano wielkiemu przeorowi Niemiec, Jerzemu Schillingowi von Cannstattowi (1546-1554), wszczęcie procedur przeciwko „buntownikom” przed Sądem Kameralnym Rzeszy. Ten jednak zignorował polecenie zwierzchników, powiadamiając o zaistniałej sytuacji herrenmeistra Tomasza von Rungego (1545-1564) ${ }^{133}$. Zachowując życzliwość wobec baliwatu, prawdopodobnie liczył na to, że jego mistrz ureguluje zaległości finansowe względem wielkiego przeoratu Niemiec. Kiedy tak się nie stało, poprosił o interwencję kierownictwo z Malty. W konsekwencji 9 października 1553 r. Tomasz von Runge (1545-1564) został oficjalnie upomniany za nieprzestrzeganie układu z Heimbach (11 czerwca 1382 r.) ${ }^{134}$.

${ }^{126}$ Szczesiak i Gahlbeck 2014, s. 211.

${ }^{127}$ Gahlbeck 2017a, s. 124.

${ }^{128}$ Kletke 1876, s. 106.

${ }^{129}$ Opgenoorth 1963, s. 67.

${ }^{130}$ Rödel 1994, s. 38.

${ }^{131}$ Gahlbeck 2017a, s. 123.

${ }^{132}$ Starnawska 1992, s. 28

${ }_{133}$ Opgenoorth 1963, s. 103.

${ }^{134}$ Rödel 1994, s. 38-39. 
Herrenmeister prawdopodobnie zlekceważył otrzymane wytyczne, dlatego powstały plany pozbawienia go urzędu. W 1558 r. wielki przeor Niemiec, Jerzy von Hohenheim (1554-1567), wysłał do baliwatu Joachima Sparra, pochodzącego z Brandenburgii komtura Moguncji (niem. Mainz, NadreniaPalatynat, miasto na prawach powiatu) i Nieder-Weisel (obecnie część Butzbach, Hesja, powiat Wetterau), który miał zyskać przychylność tamtejszych braci, a następnie stanąć na ich czele na mocy bulli wielkiego mistrza zakonu, Jeana de la Valettego (1557-1568). Kapituła baliwatu, która zebrała się w Słońsku 20 marca 1561 r., odrzuciła jednak jego roszczenia ${ }^{135}$.

W latach 70. XVI w. herrenmeister Marcin von Hohenstein (1569-1609) zdecydowanie manifestował swoje poglądy religijne. W 1577 r. razem z wieloma innymi przedstawicielami stanów brandenburskich wyraził poparcie wobec „Formuly zgody” (Formula Concordiae) - jednej z ksiąg wyznaniowych luteranizmu. Miało to duże znaczenie dla braci, którym przewodził, zwłaszcza że część z nich nadal była katolikami ${ }^{136}$. Jego postawa wzburzyła wielkiego mistrza Jeana de la Cassièrego (1572-1581), który podjął decyzję o wykluczeniu z baliwatu brandenburskiego wszystkich protestantów ${ }^{137}$.

Dyrektywy mistrza nie wykonano. Wielki przeor Niemiec, Filip Flach von Schwarzenberg (1573-1594), nie poinformował o niej Marcina von Hohensteina (1569-1609), którego postanowił bronić przed zwierzchnikami z Malty. Kierownictwo zakonu zrozumiało wówczas, że rekatolicyzacja baliwatu brandenburskiego jest niemożliwa ${ }^{138}$. Brano pod uwagę jeszcze wypowiedzenie układu z Heimbach (11 czerwca 1382 r.), ale zdano sobie sprawę z tego, że takie działanie $\mathrm{w}$ rzeczywistości niewiele by zmieniło. Ostatecznie postawiono na wykonanie symbolicznego gestu i w maju 1589 r. powołano na Malcie katolickiego mistrza baliwatu brandenburskiego, któremu jednak nie nadano tytułu herrenmeistra. Urząd ten istniał aż do 1798 r. Baliwat brandenburski pozostał częścią katolickiego zakonu joannitów, ale jego więzi z centralą i wielkim przeoratem Niemiec nie były już tak silne jak przed reformacją ${ }^{139}$.

${ }^{135}$ Opgenoorth 1963, s. 104-105; Sarnowsky 2006, s. 135.

${ }^{136}$ Zob. Floto 2003, s. 61; Kaak 2014, s. 477.

${ }^{137}$ Rödel 1994, s. 40.

${ }^{138}$ Co ciekawe, w latach 1625-1640 mistrzem baliwatu był katolik, Adam von Schwarzenberg, który jednak zobowiązał się do nie naruszania istniejącego ładu. W rezultacie baliwat pozostał protestancki. Zob. von Winterfeld 1859, s. 732-735.

${ }^{139}$ Rödel 1994, s. 40-41; Clark 2013, s. 13-14. 


\section{PODSUMOWANIE I WNIOSKI}

Baliwat brandenburski był jednostką organizacyjną w zakonie joannitów. Powstał w XIV w. w wielkim przeoracie Niemiec. W procesie jego ksztaltowania kluczowe znaczenie miała kasata zakonu templariuszy i przejęcie ich dóbr przez joannitów na mocy bulli papieża Klemensa V „Ad providam” z 2 maja $1312 \mathrm{r}$.

Podstawą funkcjonowania baliwatu były komturie położone w Brandenburgii, Meklemburgii, Saksonii i na Pomorzu Zachodnim, choć tymczasowo obejmował on również siedziby zakonne znajdujące się w innych regionach, np. w Turyngii czy na Pomorzu Gdańskim. Na jego obszarze wykształciły się także przeoraty. Były to konwenty braci-kapelanów, które istniały przy wybranych kościołach parafialnych (m.in. w Brunszwiku, Groß Eichsen i Lychen ). Na ich czele stał kapłan tytułowany przeorem.

Kościoły parafialne, szczególnie te położone w miastach i miasteczkach, takich jak: Chojna, Choszczno, Lychen, Łagów, Sławno, Słońsk, Sulęcin, Stargard czy Werben, były dla joannitów bardzo ważne. Zapewniały im stałe dochody, umożliwiały sprawowanie działalności duszpasterskiej, były doskonałymi miejscami do prowadzenia polityki. Szpitalnicy utracili większość z nich w dobie reformacji. Przyczyniło się to do zaniku kapłanów zakonnych $\mathrm{w}$ baliwacie i marginalizacji inicjatyw duszpasterskich na jego obszarze w II połowie XVI w.

Jednostka uzyskała częściową autonomię na skutek układu z wielkim przeorem Niemiec, zawartego w Heimbach 11 czerwca 1382 r. Jej przejawem było m.in. prawo wyboru mistrza przez kapitułę baliwatu. Wcześniej był on urzędnikiem mianowanym przez kierownictwo zakonu. Zwierzchnik baliwatu był tytułowany $\mathrm{w}$ średniowiecznych dokumentach preceptorem (najczęściej generalnym) albo baliwem, a od czasów reformacji herrenmeistrem.

W 1415 r. król niemiecki Zygmunt Luksemburski nakazał mistrzowi Reimarowi von Güntersbergowi (1399-1418) złożyć hołd lenny nowemu elektorowi i margrabiemu brandenburskiemu, Fryderykowi I (1415-1440). W ten sposób baliwat popadł w polityczną zależność od rodu Hohenzollernów, wyjątkowo silną za panowania Jana z Kostrzyna (1535-1571).

Margrabia, po dokonaniu konwersji na luteranizm (w 1538 r.), rozważał sekularyzację baliwatu. Dostrzegł w nim jednak szansę na rozszerzenie swoich wpływów i możliwość ingerowania w politykę wewnętrzną sąsiednich państw. Struktury zakonne pragnął wykorzystać jako przestrzeń dla swoich protegowanych, wpływając m.in. czterokrotnie na wybór herrenmeistra 
(w 1544, 1545, 1564 i 1569 r.). Chcąc sprawować ścisły nadzór nad kierownictwem baliwatu, doprowadził do tego, że zamek w Słońsku, położony raptem $11 \mathrm{~km}$ od Kostrzyna nad Odrą, został w latach 40. XVI w. stałą siedzibą jego mistrzów. Warto zauważyć, że oficjalne uznanie margrabiego patronem baliwatu w 1544 r. częściowo legitymizowało podejmowane przez niego działania.

Silny wpływ na funkcjonowanie baliwatu brandenburskiego wywarła reformacja. Zmiany, które go dotknęły, można rozpatrywać na kilku płaszczyznach:

1) religijnej:

- konwersja braci zakonnych na luteranizm i protestantyzacja baliwatu,

- laicyzacja i nieprzestrzeganie zakonnej reguły,

- zanik życia konwentualnego,

- utrata wpływów w kościołach parafialnych,

- zanik księży zakonnych,

- marginalizacja działalności duszpasterskiej,

- akceptacja ordynacji kościelnych wprowadzonych w 1540 r. na obszarze Nowej Marchii i Marchii Elektorskiej,

2) politycznej:

- osłabienie pozycji mistrza baliwatu (herrenmeistra),

- wzrost rangi komturów (np. poprzez łączenie ich funkcji z urzędem landwójta),

- zagrożenie ze strony poszczególnych władców (meklemburskich, pomorskich, brunszwickich, brandenburskich),

- sekularyzacja posiadłości zakonnych (np. komturii w Kraak - 1547 r. i przeoratu w Groß Eichsen - 1552 r.),

- utrata wpływów w komturiach (m.in. w Nemerow, Mirow i Swobnicy),

- silne podporządkowanie baliwatu margrabiemu Janowi z Kostrzyna (1535-1571),

3) ekonomicznej:

- osłabienie baliwatu poprzez sekularyzację posiadłości zakonnych,

- utrata komturii i przeoratów (m.in. Suchań, Chwarszczany, Kraak, Groß Eichsen),

- utrata dochodów z parafii,

- rosnące należności wobec wielkiego przeoratu Niemiec, 
4) obyczajowej:

- małżeństwa braci zakonnych (kapituła prowincjalna dopuściła możliwość ich zawierania przez joannitów z baliwatu brandenburskiego w 1544 r.),

- przystosowanie komturii do potrzeb kobiet oraz dzieci,

- zanik życia konwentualnego,

5) instytucjonalnej (wewnątrzzakonnej):

- ustanowienie Słońska stałą siedzibą mistrzów i ośrodkiem administracji baliwatu (od lat 40. XVI w.),

- zmiana tytulatury mistrza baliwatu, którego od czasów reformacji określano herrenmeistrem,

- napięcia $\mathrm{w}$ relacjach ze zwierzchnikami $\mathrm{z}$ wielkiego przeoratu Niemiec i Malty,

- powołanie na Malcie katolickiego mistrza baliwatu brandenburskiego w maju 1589 r. (akt symboliczny; urząd istniał do 1798 r.),

- rozluźnienie więzi strukturalnych pomiędzy baliwatem brandenburskim a pozostałą częścią zakonu.

Pomimo zmian, które dotknęły baliwat brandenburski w XVI w., pozostał on częścią katolickiego zakonu joannitów, ale jego charakter nigdy już nie był taki sam jak przed reformacją.

\section{THE BAILIWICK OF BRANDENBURG OF THE ORDER}

\section{OF SAINT JOHN UNTIL THE END OF THE $16^{\mathrm{TH}}$ CENTURY:}

\section{A HISTORICAL OUTLINE. THE IMPACTS OF THE REFORMATION}

\section{Summary}

The Bailiwick of Brandenburg was an organisational unit within the Order of Saint John, which emerged in the 14th century as part of the Great Priory of Germany. Its functioning relied on the commanderies in Mecklenburg, Saxony, and Western Pomerania, though it temporarily encompassed houses of the order elsewhere, e.g. in Thuringia and the Danzig Pomerania. It was headed by a master, whom medieval documents call preceptor (most often preceptor general) or bailiff, as well as Herrenmeister in the period following the Reformation. He was aided in the administration of the bailiwick by a chapter composed largely of commanders. The bailiwick gained autonomy within the Great Priory of Germany as a result of the Treaty of Heimbach, concluded on 11 June 1382. In 1415, in the wake of decision 
of Sigismund of Luxembourg, it came under the influence of Frederick William I, Elector of Brandenburg. Political dependence on the house of Hohenzollern increased in the age of Reformation, due to margrave John of Brandenburg-Küstrin, a staunch Lutheran who contributed to the priory's shift from a Catholic to a Protestant entity.

\section{Bibliografia}

\section{Źródła rękopiśmienne}

Obowiązek parafii Marxdorf do corocznej opłaty 7 wispli owsa na rzecz mistrza baliwatu brandenburskiego joannitów, Brandenburgisches Landeshauptarchiv in Potsdam, Rep. 9B, Johanniterorden, 7764.

Zygmunt Luksemburski nakazuje mistrzowi baliwatu złożyć hołd lenny Fryderykowi Hohenzollernowi, Brandenburgisches Landeshauptarchiv in Potsdam, Rep. 9B, Johanniterorden U. 218.

\section{Źródła drukowane}

Baron A., Pietras H. (oprac.) 2003, Dokumenty soborów powszechnych. Tekst grecki, łaciński, polski, 2 (869-1312), Kraków.

Heinemann O. (oprac.) 1905, Pommersches Urkundenbuch, 5, 2: 1317-1320, Stettin.

Kletke K. (oprac.) 1876, Regesta Historiae Neomarchicae. Die Urkunden zur Geschichte der Neumark und des Landes Sternberg, 3: Markgraf Johann (Hans) von Küstrin. 1513-1571, Märkische Forschungen, 13, Berlin.

Kodeks Dyplomatyczny Wielkopolski: obejmujący dokumenta tak już drukowane, jak dotąd nie ogłoszone, sięgające roku 1400, wydany staraniem Towarzystwa Przyjaciół Nauk Poznańskiego 1879, 3: 1350-1399, Poznań.

Konopnicka-Szatarska M. (oprac.) 2001, List Jana z Kostrzyna potwierdzający prawa do sekularyzacji zakonu joannitów oraz innych dóbr kościelnych (1538-1539), [w:] W. Strzyżewski (red.), Rola szlachty w kształtowaniu oblicza społeczno-gospodarczego Nowej Marchii (XVI-XVIII w.), Rocznik Lubuski 27, 1, Zielona Góra, s. 171-172.

Riedel A.F. (oprac.) 1846, Codex diplomaticus Brandenburgensis. Sammlung der Urkunden, Chroniken und sonstigen Geschichtsquellen für die Geschichte der Mark Brandenburg und ihrer Regenten, 2, 3, Berlin.

Riedel A.F. (oprac.) 1858, Codex diplomaticus Brandenburgensis. Sammlung der Urkunden, Chroniken und sonstigen Geschichtsquellen für die Geschichte der Mark Brandenburg und ihrer Regenten, 2, 6, Berlin.

Riedel A.F. (oprac.) 1859, Codex diplomaticus Brandenburgensis. Sammlung der Urkunden, Chroniken und sonstigen Geschichtsquellen für die Geschichte der Mark Brandenburg und ihrer Regenten, 1, 18, Berlin.

Riedel A.F. (oprac.) 1860, Codex diplomaticus Brandenburgensis. Sammlung der Urkunden, Chroniken und sonstigen Geschichtsquellen für die Geschichte der Mark Brandenburg und ihrer Regenten, 1, 19, Berlin.

Riedel A.F. (oprac.) 1861, Codex diplomaticus Brandenburgensis. Sammlung der Urkunden, Chroniken und sonstigen Geschichtsquellen für die Geschichte der Mark Brandenburg und ihrer Regenten, 1, 20, Berlin

Riedel A.F. (oprac.) 1863, Codex diplomaticus Brandenburgensis. Sammlung der Urkunden, Chroniken und sonstigen Geschichtsquellen für die Geschichte der Mark Brandenburg und ihrer Regenten, 1, 24, Berlin. 
Urkunden und Regesten zur Geschichte des Johanniterordens 1900, [w:] J. von Pflugk-Harttung, Der Johanniter- und der Deutsche Orden im Kampfe Ludwigs des Bayern mit der Kurie, Leipzig, s. 222-243.

\section{Opracowania}

Berwinkel R. 2012a, Emmerstedt - Templer, später möglicherweise Johanniter (Ca. 1250 bis 1312/57), [w:] J. Dolle, D. Knochenhauer (red.), Niedersächsisches Klosterbuch. Verzeichnis der Klöster, Stifte, Kommenden und Beginenhäuser in Niedersachsen und Bremen von den Anfängen bis 1810, 1, Bielefeld, s. 391-392.

Berwinkel R. 2012b, Süpplingenburg - Kollegiatstift, ab ca. 1170-1312 Templer, anschließend Johanniter (Ca. 1130-1820), [w:] J. Dolle, D. Knochenhauer (red.), Niedersächsisches Klosterbuch. Verzeichnis der Klöster, Stifte, Kommenden und Beginenhäuser in Niedersachsen und Bremen von den Anfängen bis 1810, 3, Bielefeld, s. 1403-1408.

Borchardt K. 2014, Die Johanniter und ihre Balleien in Deutschland während des Mittelalters, [w:] Ch. Gahlbeck, H.D. Heimann, D. Schumann (red.), Regionalität und Transfergeschichte. Ritterordenskommenden der Templer und Johanniter im nordöstlichen Deutschland und in Polen, Berlin, s. 63-76.

Breitsprecher A. 1940, Die Komturei Rörchen-Wildenbruch. Geschichte des Landes Bahn und Wildenbruch, Stettin.

Brzustowicz G.J. 2009, Likwidacja zakonu templariuszy w Nowej Marchii i na Pomorzu Zachodnim, Nasza Przeszłość, 111, s. 251-267.

Burzyński E. 2010, Zakon rycerski templariuszy na ziemiach Polski piastowskiej i na Pomorzu Zachodnim, Wodzisław Śląski.

Campenhausen von A. 1990, Der Johanniter-Orden (Balley Brandenburg), [w:] L. Carlen (red.), Geschichte und Recht geistlicher Ritterorden besonders in der Schweiz, Der Freiburger Veröffentlichungen aus dem Gebiete von Kirche und Staat, 30, Freiburg, s. 35-55.

Clark R.M. 2013, The Evangelical Knights of Saint John. A History of the Bailiwick of Brandenburg of the Knightly Order of St. John of the Hospital at Jerusalem, known as the Johanniter Order, Dallas.

Dellingshausen von F.A. 2011, Zakon joannitów w Nowej Marchii, [w:] E. Jaworski (red.), Nowa Marchia - prowincja zapomniana - ziemia lubuska - wspólne korzenie, Wojewódzka i Miejska Biblioteka Publiczna im. Zbigniewa Herberta, Zeszyty Naukowe, 9, Gorzów Wlkp., s. 25-55.

Dolański D., Konopnicka-Szatarska M. 2001, Ekonomiczne i religijne podłoże konfliktu między Janem z Kostrzyna a joannitami, [w:] W. Strzyżewski (red.), Rola szlachty w kształtowaniu oblicza społeczno-gospodarczego Nowej Marchii (XVI-XVIII w.), Rocznik Lubuski, 27, 1, Zielona Góra, s. 73-81.

Dzwonkowski T. 1998, Jan z Kostrzyna (1513-1571). Jeden z najwybitniejszych władców Nowej Marchii, [w:] K. Bartkiewicz (red.), Ludzie Środkowego Nadodrza. Wybrane szkice biograficzne (XII-XX wiek), Zielona Góra, s. 99-102.

Floto H. 2003, Der Rechtsstatus des Johanniterordens. Eine rechtsgeschichtliche und rechtsdogmatische Untersuchung zum Rechtsstatus der Balley Brandenburg des ritterlichen Ordens St. Johannis vom Spital zu Jerusalem, Juristische Zeitgeschichte, 5: Juristisches Zeitgeschehen - Rechtspolitik und Justiz aus zeitgenössischer Perspektive, 12, Berlin.

Gahlbeck Ch. 2007a, Grossendorf (Wielka Wieś). Kommende des Templerordens, [w:] H.D. Heimann, K. Neitmann, W. Schich i in. (red.), Brandenburgisches Klosterbuch. Handbuch der Klöster, Stifte und Kommenden bis zur Mitte des 16. Jahrhunderts, 1, Berlin, s. 543-550.

Gahlbeck Ch. 2007b, Grüneberg (Golice). Kommende des Johanniterordens, [w:] H.D. Heimann, K. Neitmann, W. Schich i in. (red.), Brandenburgisches Klosterbuch. Handbuch der Klöster, Stifte und Kommenden bis zur Mitte des 16. Jahrhunderts, 1, Berlin, s. 551-558. 
Gahlbeck Ch. 2007c, Lagow (Łagów). Kommende des Johanniterordens, [w:] H.D. Heimann, K. Neitmann, W. Schich i in. (red.), Brandenburgisches Klosterbuch. Handbuch der Klöster, Stifte und Kommenden bis zur Mitte des 16. Jahrhunderts, 2, Berlin, s. 723-743.

Gahlbeck Ch. 2007d, Zielenzig (Sulęcin), Kommende des Templerordens, [w:] H.D. Heimann, K. Neitmann, W. Schich i in. (red.), Brandenburgisches Klosterbuch. Handbuch der Klöster, Stifte und Kommenden bis zur Mitte des 16. Jahrhunderts, 2, Berlin, s. 1338-1344.

Gahlbeck Ch. 2013, Od dóbr rycerzy rozbójników do komandorii joannitów. Historia Golic w XV w., [w:] P. Migdalski (red.), Cedynia i okolice poprzez wieki, Chojna-Szczecin, s. $149-160$

Gahlbeck Ch. 2014, Lagow (Łagów) oder Sonnenburg (Słońsk). Zur Frage der Residenzbildung in der Ballei Brandenburg der Johanniter von 1317 bis 1527, [w:] Ch. Gahlbeck, H.D. Heimann, D. Schumann (red.), Regionalität und Transfergeschichte. Ritterordenskommenden der Templer und Johanniter im nordöstlichen Deutschland und in Polen, Berlin, s. 271-337.

Gahlbeck Ch. 2016, Strukturreform um der Wirtschaftlichkeit willen? Die Ballei Brandenburg der Johanniter unter Herman von Warberg nach 1350, Jahrbuch für die Geschichte Mittelund Ostdeutschlands, 62, s. 97-134.

Gahlbeck Ch. 2017a, Eine Ballei wird evangelisch. Selbstbehauptung und Wandel der Johanniter-Ballei Brandenburg in der Zeit der Reformation und des beginnenden Absolutismus, [w:] E. Bünz, H.D., Heimann, K. Neitmann (red.), Reformationen vor Ort. Christlicher Glaube und konfessionelle Kultur in Brandenburg und Sachsen im 16. Jahrhundert, Berlin, s. 106-134.

Gahlbeck Ch. 2017b, Die mecklenburgischen Ordenshäuser der Johanniter im Konflikt mit den Herzögen von Mecklenburg im 16. Jahrhundert, Ordines Militares Colloquia Torunensia Historica. Yearbook for the Study of the Military Orders, 22, s. 121-161.

Gahlbeck Ch. 2017c, Die Reformation in der Neumark unter ihrem Herrscher, Markgraf Hans von Küstrin (1535-1571), [w:] F. Göse (red.), Reformation in Brandenburg, Schriften der Landesgeschichtlichen Vereinigung für die Mark Brandenburg, Neue Folge, 8, Berlin, s. 201-264.

Gahlbeck Ch., Gebuhr R., Schumann D. 2007, Sonnenburg (Słońsk). Johanniter-Ordensschloß, [w:] H.D. Heimann, K. Neitmann, W. Schich i in. (red.), Brandenburgisches Klosterbuch. Handbuch der Klöster, Stifte und Kommenden bis zur Mitte des 16. Jahrhunderts, 2, Berlin, s. 1148-1173.

Gahlbeck Ch., Holst J.Ch., Szczesiak R. 2014, Mirow. Kommende S. Maria, S. Johannes der Täufer, [w:] W. Huschner, E. Münch, C. Neustadt, W.E. Wagner (red.), Mecklenburgisches Klosterbuch. Handbuch der Klöster, Stifte, Kommenden und Prioreien (10./11.-16. Jahrhundert), 1, Rostock, s. 481-541.

Gahlbeck Ch., Huschner W., Schumann D. 2014, Lychen. Priorei S. Johannes der Täufer, [w:] W. Huschner, E. Münch, C. Neustadt, W.E. Wagner (red.), Mecklenburgisches Klosterbuch. Handbuch der Klöster, Stifte, Kommenden und Prioreien (10./11.-16. Jahrhundert), 1, Rostock, s. 431-441.

Gahlbeck Ch., Schumann D. 2007, Quartschen (Chwarszczany). Kommende des Templerbzw. Johanniterordens, [w:] H.D. Heimann, K. Neitmann, W. Schich i in. (red.), Brandenburgisches Klosterbuch. Handbuch der Klöster, Stifte und Kommenden bis zur Mitte des 16. Jahrhunderts, 2, Berlin, s. 991-1115.

Hein D. 2009, Zamki joannitów w Polsce, Poznań.

Heutger N. 2007, Die Tempelherren einst und heute. Zum 50. Jubiläum der Reaktivierung des Tempelherren-Ordens in Deutschland, Berlin.

Hoogeweg H. 1925, Die Stifter und Klöster der Provinz Pommern, 2, Stettin.

Hope P. 1993, Kwestia sprowadzenia templariuszy do Polski. Rozwój uposażenia zakonu w Wielkopolsce, Poznański Rocznik Archiwalno-Historyczny, 1, s. 15-40.

Hope P. 1994-1995, Curia militiae templi in Liceniz. Z dziejów templariuszy na zaodrzańskim obszarze diecezji lubuskiej, Poznański Rocznik Archiwalno-Historyczny, 2/3, s. 11-18. 
Huschner W., Gahlbeck Ch., Szczesiak R. 2016, Gardow. Kommende S. Johannes der Täufer, [w:] W. Huschner, E. Münch, C. Neustadt, W.E. Wagner (red.), Mecklenburgisches Klosterbuch. Handbuch der Klöster, Stifte, Kommenden und Prioreien (10./11.-16. Jahrhundert), 1, Rostock, s. 317-328.

Huschner W., Szczesiak R., Gahlbeck Ch. 2016, Nemerow. Kommende S. Johannes der Täufer, [w:] W. Huschner, E. Münch, C. Neustadt, W.E. Wagner (red.), Mecklenburgisches Klosterbuch. Handbuch der Klöster, Stifte, Kommenden und Prioreien (10./11.-16. Jahrhundert), 1, Rostock, s. 544-578.

Jager M. 2014, Das Ordensschloss Sonnenburg (Słońsk) und das Ordenspalais am Berliner Wilhelmplatz. Anmerkungen zur neuzeitlichen Herrenmeisterachitektur der Ballei Brandenburg, [w:] Ch. Gahlbeck, H.D. Heimann, D. Schumann (red.), Regionalität und Transfergeschichte. Ritterordenskommenden der Templer und Johanniter im nordöstlichen Deutschland und in Polen, Berlin, s. 521-539.

Joost S., Neustadt C., Amelung J. 2016a, Kraak. Kommende S. Johannes der Täufer, [w:] W. Huschner, E. Münch, C. Neustadt, W.E. Wagner (red.), Mecklenburgisches Klosterbuch. Handbuch der Klöster, Stifte, Kommenden und Prioreien (10./11.-16. Jahrhundert), 1, Rostock, 403-418.

Joost S., Neustadt C., Amelung J. 2016b, Sülstorf. Kommende S. Johannes der Täufer, [w:] W. Huschner, E. Münch, C. Neustadt, W.E. Wagner (red.), Mecklenburgisches Klosterbuch. Handbuch der Klöster, Stifte, Kommenden und Prioreien (10./11.-16. Jahrhundert), 2, Rostock, s. 1093-1105.

Joost S., Neustadt C., Amelung J., Gesatzky R. 2016, Eichsen. Priorei S. Johannes der Täufer, [w:] W. Huschner, E. Münch, C. Neustadt, W.E. Wagner (red.), Mecklenburgisches Klosterbuch. Handbuch der Klöster, Stifte, Kommenden und Prioreien (10./11.-16. Jahrhundert), 1, Rostock, s. 281-299.

Kaak H. 2014, Verteidigung und Festigung der Position des Johanniterordens in der Neumark im 16. und 17. Jahrhundert, [w:] Ch. Gahlbeck, H.D. Heimann, D. Schumann (red.), Regionalität und Transfergeschichte. Ritterordenskommenden der Templer und Johanniter im nordöstlichen Deutschland und in Polen, Berlin, s. 467-496.

King E.J. 2016, Szpitalnicy w Ziemi Świętej, przekł. K. Ziółkowski, Oświęcim.

Klassa B. 2001, Zakon joannitów i początki jego obecności w Starogardzie Gdańskim, [w:] H. Paner, J. Stachulski (red.), Szpitalnicy św. Jana na Ziemi Starogardzkiej, Starogard Gdański, s. 15-50.

Klassa B. 2012, Siedziby joannitów na ziemiach polskich do 1312 roku, Zielona Góra.

Knüvener P. 2014, Die Kommende Tempelhof und ihre mittelalterlichen Kunstwerke, [w:] Ch. Gahlbeck, H.D. Heimann, D. Schumann (red.), Regionalität und Transfergeschichte. Ritterordenskommenden der Templer und Johanniter im nordöstlichen Deutschland und in Polen, Berlin, s. 394-411.

Kołosowski P., Siemińska D. 2014, The Templars' sites in Rurka (Rörchen) and Chwarszczany (Quartschen) in the light of the latest studies, [w:] Ch. Gahlbeck, H.D. Heimann, D. Schumann (red.), Regionalität und Transfergeschichte. Ritterordenskommenden der Templer und Johanniter im nordöstlichen Deutschland und in Polen, Berlin, s. 442-451.

Kozłowska B. 1994, Posiadłości joannitów na Pomorzu Zachodnim i Ziemi Lubuskiej (XII-XV w.), Zeszyty Naukowe Uniwersytetu Szczecińskiego, 140, Szczecińskie Studia Historyczne, 8, s. 5-24.

Lange T.W. 1994, Joannici na Pomorzu Gdańskim. Stan badań - interpretacje - próba syntezy, Zapiski Historyczne, 59, 4, s. 7-19.

Lange T.W. 1999, Szpitalnicy, joannici, kawalerowie maltańscy, Warszawa.

Lüpke H. 1933, Das Land Tempelburg. Eine historisch-geographische Untersuchung, Baltische Studien, Neue Folge, 35, s. 43-97. 
Mackensen-Astfeld von H. 1977, Die Herrenmeister der Balley Brandenburg, [w:] A. Wienand (red.), Der Johanniter-Orden, der Malteser-Orden. Der ritterliche Orden des hl. Johannes vom Spital zu Jerusalem. Seine Aufgaben, seine Geschichte, Köln, s. 630.

Majewski M. 2001, Joannici stargardzcy oraz dzieje i architektura kościoła św. Jana w Stargardzie (do Reformacji), [w:] W. Łysiak (red.), Życie dawnych Pomorzan. Materiały z konferencji, Bytów, 20-21 października 2000, Bytów-Poznań, s. 71-80.

Milewska M. 1993, Zamek w Skarszewach. Próba rekonstrukcji dziejów założenia, Pomorania Antiqua, 15, s. 141-153.

Mollwo L. 1926, Markgraf Hans von Küstrin, Hildesheim-Leipzig.

Nekanda-Trepka J. 2004, Średniowieczne początki zamku pojoannickiego w Słońsku, [w:] M. Glińska, K. Kroman, R. Makała (red.), Terra Transoderana. Sztuka Pomorza Nadodrzańskiego i dawnej Nowej Marchii w średniowieczu, Szczecin, s. 161-172.

Nève de M., Cante M., Wittkopp B. 2007, (Berlin-) Tempelhof. Kommende des Templer- bzw. Johanniterordens, [w:] H.D. Heimann, K. Neitmann, W. Schich i in. (red.), Brandenburgisches Klosterbuch. Handbuch der Klöster, Stifte und Kommenden bis zur Mitte des 16. Jahrhunderts, 2, Berlin, s. 1275-1288.

Nicholson H. 2001, The Knights Hospitaller, Woodbridge.

Opgenoorth E. 1963, Die Ballei Brandenburg des Johanniterordens im Zeitalter der Reformation und Gegenreformation, Beihefte zum Jahrbuch der Albertus-Universität Königsberg/ Pr., 24, Würzburg.

Partenheimer L. 2014, Die Johanniterkommende Werben (Altmark) von 1160 bis zur Reformation, [w:] Ch. Gahlbeck, H.D. Heimann, D. Schumann (red.), Regionalität und Transfergeschichte. Ritterordenskommenden der Templer und Johanniter im nordöstlichen Deutschland und in Polen, Berlin, s. 173-203.

Partenheimer L., Knüvener P. 2007, Werben. Kommende des Johanniterorden, [w:] H.D. Heimann, K. Neitmann, W. Schich i in. (red.), Brandenburgisches Klosterbuch. Handbuch der Klöster, Stifte und Kommenden bis zur Mitte des 16. Jahrhunderts, 2, Berlin, s. 1289-1304.

Przybył M. 2006, Hus Lagow. Z dziejów komandorii joannitów w Łagowie, [w:] D.A. Sikorski, A.M. Wyrwa, (red.), Cognitioni gestorum. Studia z dziejów średniowiecza dedykowane Profesorowi Jerzemu Strzelczykowi, Poznań, s. 395-404.

Radacki Z. 1976, Średniowieczne zamki Pomorza Zachodniego, Warszawa.

Radacki Z. 2005/2006, Średniowieczne zamki na Pomorzu Zachodnim. Suplement do monografii z 1976 roku, Materiały Zachodniopomorskie. Nowa Seria, 2/3, 2, s. 5-48.

Rödel G.W. 1972, Das Großpriorat Deutschland des Johanniter-Ordens im Übergang vom Mittelalter zur Reformation anhand der Generalvisitationsberichte von 1494/95 und 1540/41, Köln.

Rödel W.G. 1994, Catholic and Protestant Members in the German Grand Priory of the Order of St John: the Development of the Bailiwick of Brandenburg, [w:] M. Barber (red.), Fighting for the Faith and Caring for the Sick, The Military Orders, 1, Aldershot, s. 34-41.

Rymar E. 2002, Komandoria chwarszczańska templariuszy i joannitów (1232-1540), Nadwarciański Rocznik Historyczno-Archiwalny, 9, s. 11-47.

Rymar E. 2003, Kolińska komturia na tle dawnych dziejów stargardzkich joannitów, Stargardia, 3, s. 49-70.

Rymar E. 2012, Z dawnych dziejów przyodrzańskiej Nowej Marchii, Chojna.

Rymar E. 2015, Historia polityczna i społeczna Nowej Marchii w średniowieczu (do roku 1535), Gorzów Wlkp.

Sarnowsky J. 2001, Die mittelalterliche Ballei Brandenburg der Johanniter: Rezeption und Wirklichkeit, Ordines Militares Colloquia Torunensia Historica, 11, s. 165-182.

Sarnowsky J. 2006, Vorgeschichte und Anfänge der Reformation in der Ballei Brandenburg des Johanniterordens, [w:] J.A. Mol, K. Militzer, H.J. Nicholson (red.), The Military Orders and the Reformation. Choices, State building, and the Weight of Tradition. Papers of the Utrecht Conference, 30 September-2 October 2004, Hilversum, s. 119-138. 
Sawicki D. 2004, Zakony rycerskie epoki wypraw krzyżowych: powstanie, organizacja i losy kilku zakonów, Elpis. Czasopismo Teologiczne Katedry Teologii Prawosławnej Uniwersytetu w Białymstoku, 6, 9-10, s. 145-205.

Schilling E.J., Stege E. 2012, Westminster Ziemi Lubuskiej. 500 lat joannickiego kościoła zakonnego w Sonnenburgu/Słońsku (1508-2008) na tle rozwoju miasta, Słońsk.

Schirmeister O. 1994, Wietersheim - Johanniter, [w:] K. Hengst (red.), Westfälisches Klosterbuch. Lexikon der vor 1815 errichteten Stifte und Klöster von ihrer Gründung bis zur Aufhebung, 2, Münster, s. 489-493.

Schmook R. 2005, Kształtowanie władzy w epoce renesansu na przykładzie margrabiego Jana Brandenburskiego - Jana z Kostrzyna (Johann von Brandenburg - Hans von Küstrin), [w:] E. Jaworski (red.), Nowa Marchia - prowincja zapomniana - wspólne korzenie, Wojewódzka i Miejska Biblioteka Publiczna, Zeszyty Naukowe, 3, Gorzów Wlkp., s. 45-54.

Schultze J. 1989a, Die Mark Brandenburg, 3: Die Mark Brandenburg unter Herrschaft der Hohenzollern (1415-1535), Berlin.

Schultze J. 1989b, Die Mark Brandenburg, 4: Von der Reformation bis zum Westfälischen Frieden (1535-1648), Berlin.

Schumann D. 2006, Zamek i kościół joannitów w Słońsku, [w:] E. Jaworski, D. Handt, Z. Czarnuch, G. Kostkiewicz-Górska, Joannici i ich mistrz Jan Maurycy von NassauSiegen (1604-1679). Materiały z konferencji naukowej zorganizowanej przez Polsko-Niemieckie Stowarzyszenie Educatio Pro Europa Viadrina Stiftung Brandenburg, Gorzów Wlkp. 9 października 2004, Gorzów Wlkp., s. 49-66.

Schumann D. 2014, Die mittelalterlichen Ordensbauten der ehemaligen Templerkommenden in Lietzen und Quartschen (Chwarszczany). Konzepte sakraler Architekturgestaltung im späten 13. Jahrhundert, [w:] Ch. Gahlbeck, H.D. Heimann, D. Schumann (red.), Regionalität und Transfergeschichte. Ritterordenskommenden der Templer und Johanniter im nordöstlichen Deutschland und in Polen, Berlin, s. 425-433.

Sire H.J.A. 2000, Kawalerowie maltańscy, przekł. H. Szczerkowska, Warszawa.

Skaziński B. 2011, Zamek joannitów w Słońsku, Słońsk.

Smoliński M. 1998, W sprawie domów joannickich w Starogardzie i Lubiszewie w bulli papieża Grzegorza IX z 1238 roku, [w:] B. Śliwiński (red.), Szlachta, starostowie, zaciężni. Gdańskie Studia z Dziejów Średniowiecza, 5, Gdańsk-Koszalin, s. 221-238.

Smoliński M. 2008, Joannici w polityce książąt polskich i pomorskich od połowy XII do pierwszego ćwierćwiecza XIV wieku, Gdańsk.

Spieker Ch.W. 1839, Geschichte der Einführung der Reformation in die Mark Brandenburg. Zur dritten Säkularfeier am 1 November 1839, Berlin.

Starnawska M. 1991, Joannici śląscy i pomorsko-brandenburscy w późnym średniowieczu dwa modele przeobrażeń zakonu w dobie pokrucjatowej, Poznańskie Towarzystwo Przyjaciół Nauk, Sprawozdania Wydziału Nauk o Sztuce, 108, s. 25-38.

Starnawska M. 1992, Mnisi - rycerze - szlachta. Templariusze i joannici na pograniczu wielkopolsko-brandenbursko-pomorskim, Kwartalnik Historyczny, 1, s. 3-31.

Starnawska M. 1999, Między Jerozolimą a Łukowem. Zakony krzyżowe na ziemiach polskich w średniowieczu, Warszawa.

Starnawska M. 2000, Zarys dziejów joannitów na ziemiach polskich w średniowieczu, [w:] S.K. Kuczyński (red.), Zakon Maltański w Polsce, Warszawa, s. 7-39.

Steinführer H. 2012a, Braunschweig. Johanniter (Nach 1173 bis 1528), [w:] J. Dolle, D. Knochenhauer (red.), Niedersächsisches Klosterbuch. Verzeichnis der Klöster, Stifte, Kommenden und Beginenhäuser in Niedersachsen und Bremen von den Anfängen bis 1810, 1, Bielefeld, s. 138-141.

Steinführer H. 2012b, Braunschweig - Templer (Nach 1173 bis 1312/57), [w:] J. Dolle, D. Knochenhauer (red.), Niedersächsisches Klosterbuch. Verzeichnis der Klöster, Stifte, Kommenden und Beginenhäuser in Niedersachsen und Bremen von den Anfängen bis 1810, 1, Bielefeld, s. 142-143. 
Stróżyk P. 1992, Fundacja preceptorii templariuszy w Tempelhof, Roczniki Historyczne, 58, s. 5-22.

Szczesiak R., Gahlbeck Ch. 2014, Die Kommenden der Johanniter in Mirow, Gardow und Nemerow in der Herrschaft Stargard in Südmecklenburg, [w:] Ch. Gahlbeck, H.D. Heimann, D. Schumann (red.), Regionalität und Transfergeschichte. Ritterordenskommenden der Templer und Johanniter im nordöstlichen Deutschland und in Polen, Berlin, s. 204-247.

Vogel W. 2006, Terytorium Nowej Marchii na przestrzeni wieków, [w:] E. Jaworski (red.), Nowa Marchia - prowincja zapomniana - wspólne korzenie, Wojewódzka i Miejska Biblioteka Publiczna, Zeszyty Naukowe, 6, Gorzów Wlkp., s. 79-92.

Wachowiak B., Kamieński A. 2001, Dzieje Brandenburgii-Prus na progu czasów nowożytnych (1500-1701), Historia Prus. Narodziny - mocarstwo - obumieranie, 1, Poznań.

Waschinski E. 1904, Geschichte der Johanniterkomturei und Stadt Schöneck Westpr. mit einem Anhang von Urkunden, Danzig.

Wasilkiewicz K. 2016a, Templariusze i joannici w biskupstwie lubuskim (XIII-XVI w.), Acta Humanistica Gnesnensia, 10, Gniezno.

Wasilkiewicz K. 2016b, Posiadłości kameralne mistrzów baliwatu brandenburskiego joannitów na obszarze diecezji lubuskiej do końca XV w. - zarys problematyki, In gremium. Studia nad historia, kulturą i polityką, 10, s. 59-73.

Wigger A., Schumann D. 2007, Lietzen. Kommende des Templer- bzw. Johanniterordens, [w:] H.D. Heimann, K. Neitmann, W. Schich i in. (red.), Brandenburgisches Klosterbuch. Handbuch der Klöster, Stifte und Kommenden bis zur Mitte des 16. Jahrhunderts, 2, Berlin, s. 805-815.

Wilgeroth C.O. 2012, Goslar. Johanniter (Vor 1214 bis Mitte 16. Jh.), [w:] J. Dolle, D. Knochenhauer (red.), Niedersächsisches Klosterbuch. Verzeichnis der Klöster, Stifte, Kommenden und Beginenhäuser in Niedersachsen und Bremen von den Anfängen bis 1810, 2, Bielefeld, s. 519-522.

Winterfeld von A. 1859, Geschichte des Ritterlichen Ordens St. Johannis vom Spital zu Jerusalem. Mit besonderer Berücksichtigung der Ballei Brandenburg oder des Herrenmeisterthums Sonnenburg, Berlin.

Weber M. 2002, Die Süpplingenburger Dorfchronik, Süpplingenburg.

Wohlbrück S.W. 1832, Geschichte des ehemahligen Bisthums Lebus und des Landes dieses Nahmens, 3, Berlin.

Wybranowski D. 1995, Przyczynek do genezy i rozwoju komandorii joannitów w Sławnie do połowy XIII w., [w:] J. Hauziński (red.), Pomorze słowiańskie i jego sąsiedzi X-XV w., Pomerania Mediaevalis, Gdańsk, s. 75-92.

Wybranowski D. 1999, Fundacja komandorii joannitów w Goleniowie na tle stosunków księcia Bogusława IV z zakonami rycerskimi w latach 1280-1291, Przegląd Zachodniopomorski, 14 (43), 3, s. 9-23.

Wybranowski D. 2001, Jeszcze raz o konflikcie Barnima I z joannitami ze Stargardu i Korytowa z lat 1268-1271. Próba identyfikacji osób wasali książęcych z dokumentów Alberta Wielkiego, Przegląd Zachodniopomorski, 16 (45), 3, s. 7-40.

Wybranowski D. 2016, Działalność i skład osobowy domów zakonu joannitów w Księstwie Pomorskim w pierwszej połowie XIV wieku, [w:] B. Możejko, M. Smoliński, S. Szybkowski (red.), Studia z Dziejów Sredniowiecza, 20, Warszawa-Bellerive-sur-Allier, s. 339-370. 